Peaceful Islamist Mobilization in the Muslim World 
This page intentionally left blank 


\title{
Peaceful Islamist Mobilization in the Muslim World
}

\author{
What Went Right
}

Julie Chernov Hwang

\section{palgrave macmillan}




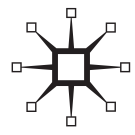

PEACEFUL ISLAMIST MOBILIZATION IN THE MUSLIM WORLD

Copyright (C) Julie Chernov Hwang, 2009.

Softcover reprint of the hardcover 1st edition 2009 978-0-230-61767-4

All rights reserved.

First published in 2009 by

PALGRAVE MACMILLAN® in the

United States - a division of St. Martin's Press LLC,

175 Fifth Avenue, New York, NY 10010.

Where this book is distributed in the UK, Europe and the rest of the world, this is by Palgrave Macmillan, a division of Macmillan Publishers Limited, registered in England, company number 785998, of Houndmills, Basingstoke, Hampshire RG21 6XS.

Palgrave Macmillan is the global academic imprint of the above companies and has companies and representatives throughout the world.

Palgrave ${ }^{\circledR}$ and Macmillan ${ }^{\circledR}$ are registered trademarks in the United States, the United Kingdom, Europe and other countries.

ISBN 978-0-230-12070-9 ISBN 978-0-230-10011-4 (eBook)

DOI $10.1057 / 9780230100114$

Library of Congress Cataloging-in-Publication Data.

Chernov Hwang, Julie.

Peaceful Islamist mobilization in the Muslim world: what went right / Julie Chernov Hwang.

p. $\mathrm{cm}$.

Includes bibliographical references and index.

1. Political participation-Islamic countries. 2. Islam and politics. 3. Political parties-Islamic countries. 4. Islamic countries-Politics and government. I. Title.

JQ1852.A91C44 2009

323'.042091767—dc22

A catalogue record of the book is available from the British Library.

Design by Macmillan Publishing Solutions.

First edition: October 2009

10987654321 
For Dae 
This page intentionally left blank 


\section{Contents}

List of Figures $\quad$ ix

List of Tables $\quad$ xi

Acknowledgments xiii

Abbreviations and Acronyms xvii

1 Introduction 1

2 Islamist Mobilization and Variation in the Turkish State 23

3 Does Participation Matter? Effective Authoritarianism in 47 New Order Indonesia

4 The Incredible Indonesian Journey: Aspiring beyond the 75 Ineffective Participatory State

5 The Effective Participatory State of Malaysia 111

6 Political Access and Public Goods in the Muslim World 139

7 Conclusion: Patterns of Mobilization 161

$\begin{array}{ll}\text { Glossary } & 175\end{array}$

$\begin{array}{ll}\text { Notes } & 181\end{array}$

$\begin{array}{ll}\text { Bibliography } & 213\end{array}$

$\begin{array}{ll}\text { Index } & 229\end{array}$ 
This page intentionally left blank 


\section{List of Figures}

Category 1.1 The Effective Participatory State 13

Category 1.2 The Effective Authoritarian State 13

Category 1.3 The Ineffective Participatory State 14

Category 1.4 The Ineffective Authoritarian State 15

Figure 7.1 Variation in Participation 163

Figure 7.2 Variation in Capacity 165 
This page intentionally left blank 


\section{List of Tables}

Table 1.1 State effectiveness versus participation

Table 4.1 Islamic and Islamist parties descended from Masyumi and Nahdlatul Ulama

Table 4.2 Indonesia's 1999 election results: People's representative assembly

Table 4.3 Indonesia's legislative election results compared: 1999 and 2004

Table 4.4 Islamist party alliances

Table 4.5 Local government regulations on morality and Sharia

Table 5.1 Malaysian government Islamization policies

Table 5.2 Parliamentary election results: Percentage vote share per party

Table 5.3 Parliamentary election results: Number of seats per party 121

Table 7.1 The variation in Islamist mobilization 
This page intentionally left blank 


\section{Acknowledgments}

I have benefited greatly from the input and sagely advice of scholars in the United States, Indonesia, Singapore, Malaysia, and Turkey. Most notably, I wish to express my profound gratitude and deep respect for Dr. William Safran, my dissertation chair and advisor at the University of ColoradoBoulder. Thank you for taking me on, as your last graduate student, and working with me through the nuts and bolts of this project. Your insight and input have been invaluable to me over the years. You have taught me what it means to be a good scholar, colleague, and mentor, not only through your advice, good humor, and subtle criticism, but also by your example.

I am also indebted to my dissertation committee: Sumit Ganguly, Fred Denny, Sven Steinmo, and Peter Gries, whose constructive comments had a profound impact on the development of this project. I am deeply grateful to Greg Barton for his advice on case selection and for his insights on radical Islam in Indonesia and progressive Islam in Indonesia and Turkey and to Steve Chan, Colin Dueck, Sam Fitch, and Kim Niles for their advice while this project was being conceptualized. I also want to thank Jenny Kehl for her suggestions on how to improve the introduction as well as Ihsan Ali Fauzi and Badrus Sholeh for their feedback on the Indonesia chapters. I am indebted to the anonymous reviewers at Palgrave, International Political Science Review, Indonesia, and Asian Security for their rigorous critiques on the Indonesia and Turkey chapters. I would also like to express my deep appreciation to Farideh Koohi-Kamali and Asa Johnson at Palgrave Press for their hard work on this project. Their advice, support, and knowledge of the market have been invaluable. Erin Ivy and the editorial teams at Palgrave Macmillan and Macmillan Publishing Solutions did a great job of sharpening the language.

In Indonesia, I wish to thank those who provided comments, who discussed their views with me, who let me interview them, and who assisted in the research and data-gathering process. This work would not have been possible without the assistance of the Freedom Institute for Democracy, 
Nationalism and Market Studies in Jakarta and the scholars who reside there: Dr. Rizal Mallarangeng, Dr. Saiful Mujani, Hamid Basyaib, Nong Darol Mahmada, Dr. Luthfi Assyaukanie, and Aan Sugianto Tandra. I want to express my gratitude to Kyai Hj Abdurrahman Wahid, Kyai Hj Hasyim Muzadi, Dr. Din Syamsuddin, Syafi'i Ma’arif, Azyumardi Azra, Abdul Mukti, Mutammimul Ula, Yoyoh Yusroh, Zulkieflimansyah, Zuhairi Misrawi, Mas'dar Masudi, Mariah Ulfah, Dr. Bahtiar Effendy, Badrus Sholeh, I.G. Wilakuda, Dr. Irwan Abdullah, Dr. Mochtar Mas'oed, Syafi Anwar, Dr. Mochtar Buchori, Kevin O'Rourke, Ichsan Ali Fauzi as well as numerous other leaders of Nahdlatul Ulama, Young NU, Fatayat Welfare Foundation, Muhammadiyah, Young Muhammadiyah, Jaringan Islam Liberal, the International Center for Islam and Pluralism, Lembaga Dakwah Kampus at UIN Syarif Hidayatullah, Hizbut Tahrir, Gerakan Ummat Anti-Pengajan, Front Pembela Islam, Majelis Mujihideen Indonesia, Partai Keadilan Sejahtera, Partai Kebangkitan Bangsa, Partai Bulan Bintang, and Partai Persatuan Pembangunan and so many others, who took time from their schedules to meet with me and discuss their organizations and their views on the role of Islam in politics, the democratic transition, and the Indonesian state. Thank you also to Jennifer Epley, who was a sounding board, a friend, and a guide through Indonesian bureaucracy. I also want to express my deep appreciation to my two research assistants, A'an Suryana in Jakarta and Imam Malik Ridwan in Yogyakarta, for being such extraordinary fixers and friends. The Indonesia portion of this project is stronger for their hard work, input, and assistance.

In Malaysia, this work would not have been possible without the help of the University of Malaya and the Center for Civilizational Dialogue. Specifically, I wish to express my sincere gratitude to Dr. Azizan Baharuddin, who made me feel welcome and gave me access to the center's contacts and provided me with a workspace and facilities. There are so many scholars, NGO leaders, and political figures who let me interview them and who shared with me their impressions of their country and why mobilization there had remained so peaceful for so long. These include former prime minister Mahathir Muhammad, Dr. Syed Ali Tawfik Al Attas, Dr. Patricia Martinez, Dato Dr. Khoo Kay Kim, Dato Dr. Shamsul Amri Baharuddin, Dr. Osman Bakar, Dr. Zainah Anwar, Dr. Noraini Othman, Dr. Clive Kessler, Dr. Rosnani Hashim, Dr. Chandra Muzaffar, Dato Shahrir Abdul Samad, Zaid Kamaruddin, Tan Sri Dato Seri Dr. Ahmad Sarji Bin Abdul Hamid, Shahran Kasim, Rita Sim, Dr. Mohammad Hazim Shah, and many others. I would like to extend sincere appreciation to those from the University of Malaya branch in Kelantan who arranged my stay in that province and those from PAS and from the state government ministries who met with me during my time in Kota Bahru. Finally, I'd also express my 
gratitude to Dr. Abdi Omar, his wife, Salmi, and their children, Shafiqah and Abdu, who welcomed me into their home and treated me as a member of the family.

In Turkey, I wish to thank those scholars, NGO leaders, and politicians who permitted me to interview them and gave me insight into this complex and unique nation. These include Dr. Ilter Turan, Dr. Tufan Buzpinar, Dr.Ihsan Dagi, Dr.Nuri Tinaz, politicians from the AKP, and members of Fetullah Gulen. I would also like to thank Ali Bardakoglu, the president of the Diyanet Isleri Baskanligi, the Directorate of Religious Affairs, for agreeing to meet with me and discuss the role and responsibilities of this ministry. In addition, I would like to extend thanks to my dear colleagues, Ozge Celik, who arranged my stay in Ankara, and Murat Ozkaleli, who provided me with key contacts and important insights about Turkish politics and culture.

Finally, I wish to express my deepest and most profound gratitude, love, and respect for my family. To my parents, thank you for your unwavering support. To the Hwangs and the Kims, thank you for your understanding. To Dae, thank you for inspiring me, for knowing when to push me and when to help me relax, and above all for not being a political scientist. Thank you for bearing all of this with me. 
This page intentionally left blank 


\section{Abbreviations and Acronyms}

ABIM Angkatan Belia Islam Malaysia (Malaysian Islamic Youth Movement)

AKP Adalet ve Kalkinma Partisi (Justice and Development Party)

AL Awami League

BA Barisan Alternatif

BN Barisan Nasional

BNP Bangladesh National Party

DAP Democratic Action Party

DDII Dewan Dakwah Islamiyah Indonesia (Indonesian Islamic Propagation Council)

FP

FPI

Fazilet Partisi (Virtue Party)

Golkar Golongan Karya (Functional Groups)

HuJI Harkat ul-Jihad-al-Islami (Movement of the Islamic Holy War)

HT Hizbut Tahrir

ICM Islamic Constitution Movement

ICMI Ikatan Cendekiawan Muslim Se-Indonesia (Association of Indonesian Muslim Scholars)

IKIM Institut Kefahamaman Islam Malaysia (Malaysian Institute for Islamic Understanding)

IOJ Islami Oikya Jote (Islamic Unity Front)

ISTAC International Institute of Islamic Thought and Civilization

JAKIM Jabatan Kemajuan Islam Malaysia (Department for the Advancement of Islam)

JI Jemaah Islamiyah (Islamic Community)

JIL Jaringan Islam Liberal (Liberal Islam Network)

JIM Jamaah Islah Malaysia (Society for Islamic Reform)

JMB Jordanian Muslim Brotherhood 
JMB Jama'atul Mujihideen Bangladesh (Community of the Mujihideen of Bangladesh)

JMJB Jagrata Muslim Janata Bangladesh (Awakened Muslim Masses of Bangladesh)

LJ Laskar Jihad (Holy War Militia)

Masyumi Majelis Syura Muslimin Indonesia (Consultative Council on Indonesian Muslims)

MDI Majelis Dakwah Indonesia (Indonesia Dawkah Council)

MMI Majelis Mujihideen Indonesia (Indonesian Holy Warriors Council)

MSP Milli Selamet Partisi (National Salvation Party)

MUI

NU

Majelis Ulama Indonesia (Indonesian Ulama Council)

PAN

Nahdlatul Ulama (Awakening of the Scholars)

PAS

Partai Amanat Nasional (National Mandate Party)

PDI-P

Partai Islam se-Malaysia (Malaysian Islamic Party)

$\begin{array}{ll}\text { PDI-P } & \text { Partai Demokrat Indonesia-Perjuangan (Indonesian Democratic } \\ & \text { Party-Struggle) } \\ \text { PBB } & \text { Partai Bulan Bintang (Crescent and Star Party) } \\ \text { PK } & \text { Partai Keadilan (Justice Party) now PKS } \\ \text { PKB } & \text { Partai Kebangkitan Bangsa (National Awakening Party) } \\ \text { PKS } & \text { Partai Keadilan Sejahtera (Prosperous Justice Party) } \\ \text { PKR } & \text { Partai Keadilan Rakyat (People's Justice Party) } \\ \text { PPP } & \text { Partai Persatuan Pembangunan (United Development } \\ & \text { Party) } \\ \text { RP } & \text { Refah Partisi (Welfare Party) } \\ \text { SARA } & \text { Suku, Agama, Ras, Antar-Golongan (Tribe, Religion, Race, } \\ & \text { Inter-Communal Relations) } \\ \text { THB } & \text { Turkish Hizballah } \\ \text { UMNO } & \text { United Malays National Organization } \\ \text { YIP } & \text { Yemeni Islah Party }\end{array}$

